\title{
0 estranho caso dos preços que querem desvincular-se do valor: contributo para uma Teoria Marxista da inflação
}

The strange case of prices that want to dissociate themselves from value: contribution to a Marxist theory of inflation

Nuno Miguel Cardoso Machado ${ }^{a}$

\begin{abstract}
Resumo: A inflação permanente é uma realidade exclusiva do período pós-2 ${ }^{a}$ Guerra Mundial. Neste artigo será defendido que a teoria de Marx é indispensável para uma explicação da inflação nas economias contemporâneas. Os fenômenos de mercado são incapazes de alterar a grandeza do valor predeterminada na esfera da produção, mas podem provocar variações nos preços de mercado. A teoria marxista da inflação enuncia que a inflação é um fenômeno monetário que toma lugar na esfera da circulação e que se caracteriza pelo desfasamento dos preços de mercado face às relações de valor subjacentes. Existem três teorias marxistas fundamentais que explicam este desfasamento corporizado na subida generalizada dos preços: i) a teoria do capital monopolista; ii) a teoria da emissão excedentária de meio circulante; iii) a teoria do conflito distributivo.
\end{abstract}

Palavras-chave: Marx; Inflação; Dinheiro; Valor; Preços. Classificação JEL: B14; B24; B31.

\begin{abstract}
Permanent inflation is a reality confined to the post-World War II period. In this article it will be argued that Marx's theory is indispensable for the accounting of inflation characteristic of contemporary economies. Market phenomena are incapable of changing the magnitude of value predetermined in the sphere of production, but they can cause variations in market prices. Marxist theory of inflation explains it as a monetary phenomenon which takes place in the sphere of circulation and that it is marked by a gap between market prices and the underlying value relations. There are three fundamental Marxist theories that explain this gap substantiated in the general rise in prices: i) the monopoly capital theory; ii) the excess supply of money as medium of circulation theory; ii) the distributive conflict theory.
\end{abstract}

Keywords: Marx; Inflation; Money; Value; Prices.

JEL Classification: B14; B24; B31.

a SOCIUS, ISEG, Universidade de Lisboa. E-mail: nuno.cocas.machado@gmail.com. 


\section{Introdução}

A inflação permanente é um fenômeno exclusivo do período pós-2a Guerra Mundial. Em particular, "a inflação jamais se apresentou em níveis tão elevados e numa variedade tão grande de países como os apresentados a partir da década de 1970" (Barbosa, 2010, p. 147). Apesar disso, a inflação tem sido um tema relativamente marginal no seio das teorias marxistas (Harvey, 2006, p. 308n11).

Neste artigo procurarei demonstrar que a teoria do dinheiro de Marx mantém a sua relevância e é imprescindível para um entendimento adequado da inflação que caracteriza as economias contemporâneas. Segundo Marx, o dinheiro não é uma simples convenção (Prado, 2013, 140), mas a forma de manifestação social do valor. A função primordial do dinheiro é aquela de medida dos valores, ou seja, o dinheiro tem de representar a substância qualitativa do valor - o trabalho abstrato -, bem como as variações da sua grandeza - o trabalho socialmente necessário. Para fazê-lo o dinheiro tem de ser ele próprio uma mercadoria na qual foi despendido um certo quantum de trabalho.

Marx estava ciente que a função de meio de circulação dissocia-se historicamente dos metais preciosos, mas defende que é a massa do valor das mercadorias produzidas que determina o volume de meio circulante, dada a velocidade de circulação. O dinheiro simbólico, enquanto meio de circulação, deverá atuar como um substituto da quantidade de ouro que seria necessária para realizar os preços das mercadorias, sob pena de desvalorização (Shortall, 1994, p. 233-234).

A teoria marxista do valor postula que o valor é determinado no interior da esfera da produção. Neste sentido, os fenômenos do mercado são incapazes de alterar essa grandeza agregada predeterminada, mas podem provocar variações dos preços de mercado. Assim, a teoria marxista da inflação - que deve ser entendida como um corolário da teoria do valor - enuncia que a inflação é um fenômeno monetário que ocorre na esfera da circulação e que se caracteriza pelo aumento generalizado dos preços de mercado. Em outros termos, ocorre um desfasamento do nível de preços face à grandeza do valor produzido socialmente.

Existem três tipos principais de teorias marxistas da inflação, que divergem quanto à causa aduzida para este desfasamento: i) $\mathrm{Na}$ ótica da teoria do capital monopolista, o poder de mercado das grandes empresas permite-lhes praticar preços de monopólio consideravelmente superiores ao valor produzido; ii) Na perspectiva da teoria da emissão excedentária de meio circulante, a inflação resulta da criação excessiva de signos monetários face às necessidades reais da economia, mormente no contexto do dinheiro fiduciário de curso forçado; iii) De acordo com a teoria do conflito distributivo, a inflação é explicada pela luta de classes entre trabalho assalariado e capital, nomeadamente pela necessidade de contrariar a queda da taxa de lucro através do aumento artificial dos preços. 


\section{Mercadoria, Valor (de troca) e Trabalho}

No Livro Primeiro de $O$ Capital, Marx começa por analisar a mercadoria, que constitui a forma "celular" da riqueza na sociedade capitalista (Marx, 1996a, p. 130). Essa análise está sintetizada esquematicamente na Figura 1. A mercadoria é a unidade contraditória de valor de uso e valor. Por um lado, é uma determinada coisa útil sensível que satisfaz uma necessidade particular: um valor de uso. Por outro lado, é o suporte de uma abstração social historicamente específica: o valor. O valor é uma categoria peculiar, porquanto é algo impalpável, intangível, suprassensível - uma forma de riqueza abstrata, mas real.

Figura 1: A Mercadoria

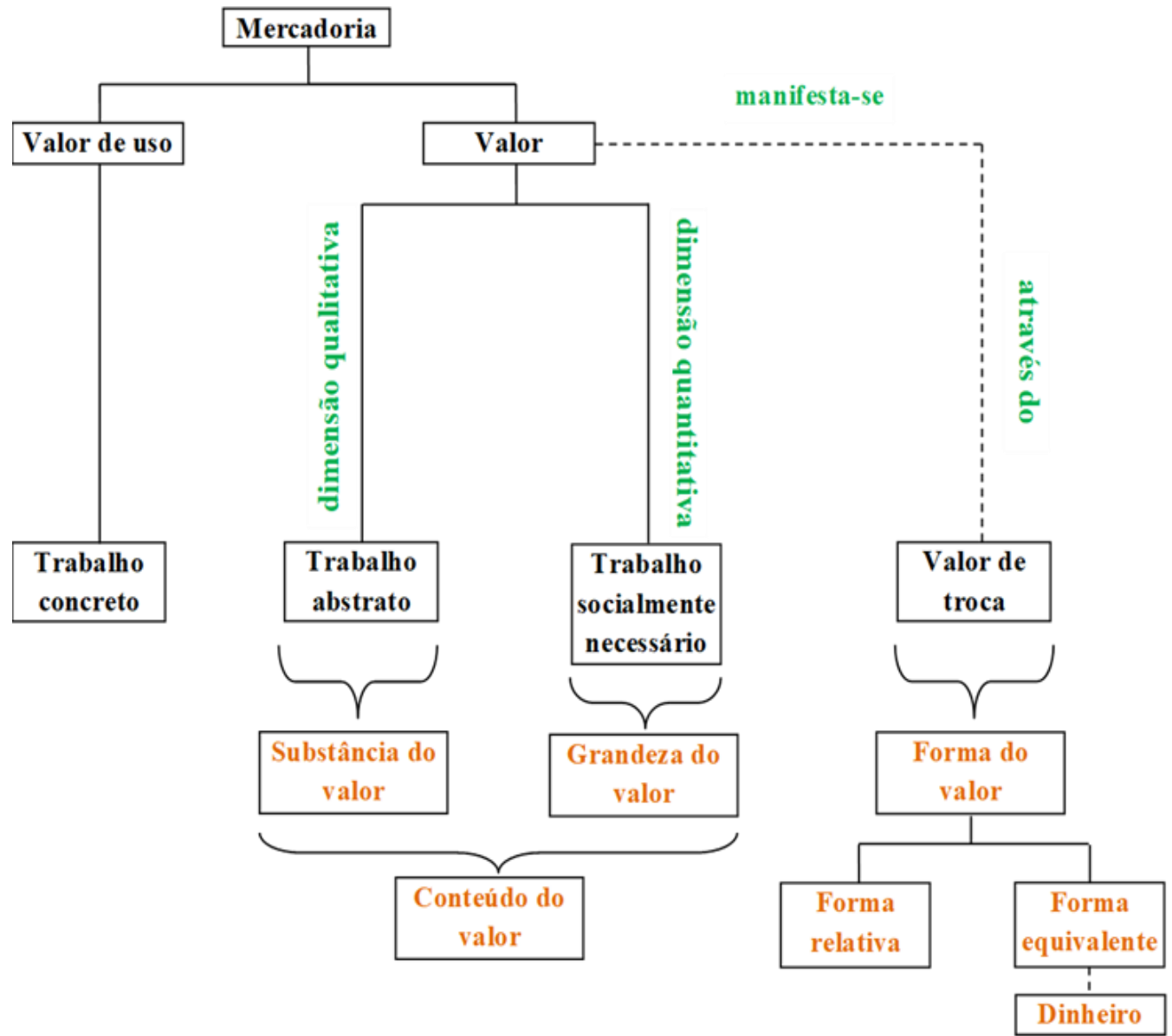

Fonte: Elaboração própria. 
A natureza dual da mercadoria é reconduzível à natureza bífida da atividade produtiva no capitalismo: o trabalho. Na medida em que produz valores de uso é um trabalho concreto. Valores de uso distintos (pão, cadeiras, etc.) exigem trabalhos "qualitativamente diferentes" (Marx, 1996a, p. 171). O trabalho concreto produz, pois, "riqueza material", concreta (Marx, 1996a, p. 172).

Por sua vez, enquanto valores, todas as "qualidades sensoriais" (Marx, 1996a, p. 167) das mercadorias e todas as "formas concretas" dos trabalhos que as produziram são apagadas (Marx, 1996a, p. 168). Portanto, para que as mercadorias possam adquirir a característica de valores - e, assim, ser comensuráveis e trocadas -, os trabalhos qualitativamente distintos despendidos na sua produção têm de ser reduzidos a "igual trabalho humano, a trabalho humano abstrato" (Marx, 1996a, p. 168). O trabalho abstrato é uma abstração real que produz valor, constituindo "a substância social comum a todas as mercadorias" (Marx, 1996b, p. 92, itálico no original).

Esta substância homogênea pode ser medida quantitativamente. A grandeza do valor é determinada pelo tempo de trabalho socialmente necessário: "aquele requerido para produzir" uma mercadoria "nas condições dadas de produção socialmente normais, e com o grau social médio de habilidade e de intensidade de trabalho" (Marx, 1996a, p. 169). O tempo de trabalho socialmente necessário é o padrão objetivo de produtividade disseminado pela economia através da concorrência e que regula a produção nos seus diversos ramos.

A grandeza do valor das mercadorias varia obviamente com as mudanças na força produtiva do trabalho. De um modo geral, "quanto maior a força produtiva do trabalho, tanto menor o tempo de trabalho exigido para a produção de um artigo, tanto menor a massa de trabalho nele cristalizada, tanto menor seu valor" (Marx, 1996a, p. 170). O conteúdo do valor é constituído pela unidade de substância e grandeza do valor. Trata-se de um trabalho abstrato qualitativamente homogêneo, cuja grandeza depende do nível médio de produtividade determinado socialmente.

Anselm Jappe relembra que tanto o trabalho abstrato como o valor por ele criado representam "abstrações sociais", ou seja, não representam nada tangível ou material (Jappe, 2006, p. 28). Assim, o valor de uma mercadoria apenas pode manifestar-se de maneira indireta através de uma forma perceptível, o valor de troca, que expressa "a relação quantitativa, a proporção na qual valores de uso de uma espécie se trocam contra valores de uso de outra espécie" (Marx, 1996a, p. 166).

A antítese entre valor de uso e valor contida na mercadoria tem de ser exteriorizada através da sua duplicação em mercadoria e dinheiro. A miríade das mercadorias encontramse na forma relativa do valor, enquanto o dinheiro desempenha a função de equivalente geral, ou seja, é o veículo material no qual são expressos os valores das demais mercadorias. As mercadorias e a mercadoria-dinheiro apenas podem ser equiparadas na troca porque possuem a mesma natureza qualitativa: ambas são o produto do trabalho abstrato. É evidente que o valor relativo de uma mercadoria pode variar quando se altera o seu próprio valor e/ou o valor da mercadoria-dinheiro. 
Em suma, o dinheiro é a "forma comum de valor" (Marx, 1996a, p. 176) das mercadorias, a sua figura autônoma. Isto significa que o corpo sensível da mercadoria que funciona como equivalente assume-se sempre como a encarnação objetiva do valor e, portanto, do trabalho abstrato e do trabalho socialmente necessário. Historicamente, a forma equivalente geral fixou-se definitivamente, "por meio do hábito social", nos metais preciosos (Marx, 1996a, p. 196), porque estes, ao possuírem uma "qualidade uniforme" na sua forma natural, fornecem a "forma adequada de manifestação do (...) trabalho humano abstrato, e portanto, igual” (Marx, 1996a, p. 214).

\section{As Funções do Dinheiro na Teoria de Marx}

\subsection{O Dinheiro como Medida dos Valores}

A primeira função do dinheiro é providenciar o material para a expressão dos valores das mercadorias, representando-as como grandezas da mesma substância qualitativa que, consequentemente, são comparáveis quantitativamente. Neste sentido, o dinheiro funciona como "medida geral dos valores" (Marx, 1996a, p. 219). Segundo Prado, "o que define o dinheiro não é a materialidade do ouro, mas o fato de esta materialidade passar a expressar a imaterialidade do valor quando recebe a forma de equivalente geral" (Prado, 2013, p. 136).

Marx recorda que não é por intermédio do dinheiro que as mercadorias se tornam comensuráveis. As mercadorias não têm um valor porque são comensuradas e trocadas; ao invés, é porque são valores que as mercadorias podem ser trocadas. Portanto, é na sua qualidade de valores, ou seja, de "trabalho humano objetivado" idêntico, que as mercadorias são comensuráveis no mesmo equivalente geral - o dinheiro (Marx, 1996a, p. 219). ${ }^{1}$

Neste sentido, o dinheiro, na sua função de medida dos valores, é a "forma necessária de manifestação da medida imanente do valor das mercadorias: o tempo de trabalho" (Marx, 1996a, 219). O dinheiro é a expressão do tempo de trabalho objetivado nas mercadorias. Existe uma relação estreita entre (tempo de) trabalho abstrato e trabalho socialmente necessário, por um lado, e dinheiro, por outro lado.

Como é evidente, o dinheiro só pode ser a medida dos valores das mercadorias - do trabalho abstrato nelas contido - porque é ele próprio uma mercadoria com um certo valor, i.e., a cristalização de um certo quantum de trabalho: "O dinheiro só é medida porque é tempo de trabalho materializado em uma substância determinada, ou seja, ele próprio é valor" (Marx, 2011, p. 666, itálico no original).

À semelhança do valor das demais mercadorias, o valor da mercadoria-dinheiro é determinado pelo tempo de trabalho socialmente necessário requerido pela sua produção e,

\footnotetext{
${ }^{1}$ Em Para a Crítica da Economia Política, Marx já tinha advertido: "Não é senão pura aparência do processo de circulação a impressão de que o dinheiro faz as mercadorias comensuráveis, pois a medida entre ouro e mercadoria é o tempo de trabalho (...). Ao contrário, não é senão a comensurabilidade das mercadorias como tempo de trabalho objetivado que permite ao ouro transformar-se em dinheiro" (Marx, 1982, p. 56-57).
} 
por conseguinte, pode ser expresso - de um modo relativo - na quantidade de qualquer outra mercadoria "em que está cristalizado o mesmo tempo de trabalho" (Marx, 1996a, p. 216). Por exemplo, se $1 \mathrm{Kg}$ de ouro for o produto de 1 hora de trabalho socialmente necessário, ele será permutável por uma quantidade de qualquer outra mercadoria na qual esteja cristalizada igualmente 1 hora de trabalho socialmente necessário.

$\mathrm{Na}$ ótica de Marx, um dinheiro desprovido de valor - que não seja uma mercadoria - é simplesmente incapaz de desempenhar a função de medida dos valores:

Quando o dinheiro é utilizado como medida do valor (...), o valor de uma mercadoria é expresso em termos de uma quantidade física de ouro. Por exemplo, uma tonelada de ferro pode ter o mesmo valor que (conter o mesmo trabalho [socialmente necessário]) que duas onças de ouro. Para que esta equação seja possível, o ouro [i.e., o dinheiro] deve ele próprio ter um valor. (Brewer, 1984, p. 29, itálico no original)

Em suma,

o que significa dizer que dinheiro é mercadoria? Significa afirmar que o dinheiro é também, tal como todas as outras [mercadorias], valor de uso e valor. Eis que é um valor porque todo montante de dinheiro contém um determinado quantum de trabalho abstrato; ademais, é valor de uso porque funciona como equivalente geral e tem várias funções na circulação das mercadorias. (Prado, 2013, p. 133)

Tal como o valor das restantes mercadorias, o valor do dinheiro muda ao longo do tempo, mas Marx realça que isso não constitui um entrave à sua função de medida dos valores. A mudança de valor do ouro repercute-se simultaneamente em todas as mercadorias, deixando inalterados os seus valores relativos, que apenas passam a expressar-se em preços - medidos em ouro - mais ou menos elevados do que anteriormente (Marx, 1996a, p. 223).

Refira-se, finalmente, que "a presença real da mercadoria-dinheiro não é requerida para que o dinheiro funcione como medida do valor" (Shortall, 1994, p. 224). Com efeito, os preços das mercadorias são inicialmente "imaginários" ou "ideais", no sentido em que cada produtor estima o preço da sua mercadoria, mas não sabe se vai conseguir realizá-lo no mercado (Harvey, 2010, p. 56). Isto significa que antes de entrarem no processo de troca, as mercadorias existem apenas enquanto "dinheiro ideal" (Marx, 2011, p. 58), expresso sob a forma do seu preço.

Deste modo, "o dinheiro faz circular somente as mercadorias já transformadas em dinheiro idealmente, não somente na cabeça do indivíduo singular, mas também na representação da sociedade" (Marx, 2011, p. 134-135, itálico no original). Apenas no momento da troca efetiva - i.e., da compra/venda - da mercadoria, é que esse dinheiro ideal tem de converter-se em dinheiro sonante desembolsado pelo comprador. ${ }^{2}$

\footnotetext{
${ }^{2}$ Mas, neste caso, o dinheiro passa a desempenhar outra função: a de meio de circulação (cf. 3.3).
} 


\subsection{O Dinheiro como Padrão de Preços}

Mesmo num sistema monetário assente no dinheiro metálico, os preços das mercadorias não são expressos diretamente em quantidades de ouro, mas em termos de uma unidade monetária (real, euro, dólar, etc.) que representa uma certa quantidade de ouro: "A medida dos valores dá-se sempre de modo indireto, por meio de um determinado padrão de preços" (Prado, s.d., p. 4). Isto significa que

os valores das mercadorias não são expressos simplesmente em termos da quantidade física da mercadoria-dinheiro - em termos de onças ou gramas de ouro - mas como preço. Assim, temos [por exemplo]: um casaco vale $£ 20$, em que estas $£ 20$ são equivalentes [por hipótese] a duas onças de ouro que, por sua vez, são o produto de $x$ horas de trabalho social abstrato. (Shortall, 1994, p. 224-225)

Deste modo, conforme salienta Suzanne De Brunhoff,

O papel do dinheiro como medida do valor envolve duas determinações complementares. (...) Marx faz uma distinção entre as características do ouro como medida do valor (o seu valor varia de acordo com as circunstâncias em que é produzido) e aquelas do ouro como padrão de preços, em que um peso do metal fixado pelo costume serve de unidade de medida que permite a comparação mútua dos preços das mercadorias, quaisquer que sejam as variações do valor do ouro. (De Brunhoff, 1976, p. 28-29, itálico no original)

O padrão de preços é, pois, "o nome atribuído a uma quantidade particular de ouro" (Brewer, 1984, p. 29) pelo Estado e que funciona como unidade de conta (De Brunhoff, 1976, p. 30), isto é, como "a unidade utilizada para definir os preços, estimá-los e reconhecê-los" (Nelson, 1999, p. 82). O padrão de preços "exerce essa função como «peso metálico fixo»" (Guerrero, 2010, p. 17). O Estado estabelece, por força de lei (Brewer, 1984, p. 29), que uma dada quantidade de ouro recebe a designação, hipoteticamente, de $x$ euros. Se o Estado determinar que "1 euro" é a denominação monetária de 10 gramas de ouro, então cunhará moedas de ouro com o peso de 10 gramas e com o valor facial de 1 euro.

O padrão de preços constitui uma denominação arbitrária (Barbosa, 2010, p. 85) que, obviamente, "não é afetada pelas mudanças de valor do ouro" (Guerrero, 2010, p. 17). Por exemplo, se 1 euro for a designação monetária de 10 gramas de ouro, essa razão de conversão ou "taxa de câmbio" manter-se-á por muito que varie a produtividade do trabalho no setor aurífero e, portanto, o tempo de trabalho socialmente necessário cristalizado nesses 10 gramas de ouro.

Todavia, por outro lado, é preciso realçar que "o Estado fixa, por convenção, um padrão de preços nacional, mas (...) não pode influenciar o valor do ouro, nem os valores de quaisquer mercadorias" (Nelson, 1999, p. 82, itálico nosso). Consideremos o seguinte exemplo: Se tanto em $1 \mathrm{Kg}$ de açúcar como em 10 gramas de ouro estiver cristalizada 1 hora de trabalho socialmente necessário, e 1 euro for a denominação monetária de 10 gramas de ouro, então $1 \mathrm{Kg}$ de açúcar terá o preço de 1 euro.

Se a produtividade no setor aurífero duplicar, então em 1 hora de trabalho socialmente necessário serão produzidos 20 gramas de ouro. Note-se que esta alteração do 
valor do ouro não provoca qualquer modificação do padrão de preços: tal como na situação inicial, 1 euro continua a ser a designação monetária de 10 gramas de ouro. Assim, a alteração do valor do ouro repercute-se somente no valor de troca do açúcar: o preço de 1 $\mathrm{Kg}$ de açúcar subirá de 1 para 2 euros, embora o seu valor não tenha sofrido qualquer alteração (1 Kg de açúcar continua a ser o produto de 1 hora de trabalho socialmente necessário, que se troca pelo produto de 1 hora de trabalho socialmente necessário no ramo aurífero, 20 gramas de ouro).

É perfeitamente claro que o trabalho socialmente necessário continua a ser a medida comum, imanente do valor, aquilo que possibilita a equação do valor das mercadorias com o valor da mercadoria-dinheiro. Neste caso, em primeiro lugar, a equação do valor de $1 \mathrm{Kg}$ de açúcar com o valor de 10 gramas de ouro e, seguidamente, do valor de $1 \mathrm{Kg}$ de açúcar com o valor de 20 gramas de ouro.

\subsection{O Dinheiro como Meio de Circulação}

\subsubsection{O Curso do Dinheiro e o Dinheiro Simbólico}

O movimento imprimido ao dinheiro pela circulação de mercadorias constitui o seu curso (Marx, 1996a, p. 237). Ele traduz a transferência sucessiva do dinheiro das mãos dos compradores para os vendedores de mercadorias. $\mathrm{O}$ dinheiro possui então uma segunda função: aquela de meio de circulação (Marx, 1996a, p. 238), isto é, de mediador da "troca efetiva das mercadorias" (Heinrich, 2012, p. 66). No cumprimento desta função, "o dinheiro é simplesmente um servidor do movimento das mercadorias” (Shortall, 1994, p. 229).

\footnotetext{
Na medida em que medeia a troca das mercadorias, i.e., nesse caso, medeia a sua circulação, logo, é meio de troca, o dinheiro é instrumento da circulação (...); porém, na medida em que, nesse processo, ele mesmo é posto a circular, gira, cumpre um movimento próprio, ele próprio tem uma circulação, circulação monetária, curso do dinheiro. (...) Se o dinheiro faz circular as mercadorias, as mercadorias fazem circular o dinheiro. Por conseguinte, a circulação das mercadorias e a circulação do dinheiro condicionam-se reciprocamente. (Marx, 2011, p. 133 134, itálico no original)
}

Marx constata que "a circulação do dinheiro, assim como a da mercadoria, parte de uma infinidade de pontos distintos e retorna a uma infinidade de pontos distintos" (Marx, 2011, p. 133). No entanto, enquanto cada mercadoria, após ter sido vendida, abandona o processo de circulação para ser consumida enquanto valor de uso, o dinheiro, pelo contrário, existe e movimenta-se sempre na esfera da circulação (Marx, 1996a, p. 238-239).

A "forma característica do dinheiro" enquanto meio de circulação é a moeda (Itoh \& Lapavitsas, 1999, p. 43). A sua cunhagem é uma tarefa que recai sobre o Estado (Itoh \& Lapavitsas, 1999, p. 43). Nos primórdios do modo de produção capitalista, as moedas eram cunhadas em metal precioso com um peso estandardizado (Marx, 1996a, p. 245). Todavia, "assim que o dinheiro metálico é cunhado em moedas com um peso padronizado, surge o 
problema do desgaste dessas moedas. A circulação constante implica que o peso das moedas caia significativamente abaixo do seu peso nominal facial" (Shortall, 1994, p. 230).

Acresce que os custos de produção da mercadoria-dinheiro são extremamente avultados (Thomas, 2009, p. 21) e improdutivos do ponto de vista da economia capitalista no seu conjunto (Mattick, 1978, p. 63). Em último lugar, a velocidade de circulação do dinheiro-ouro é lenta e, portanto, abranda o processo de circulação das mercadorias (Thomas, 2009, p. 21). Deste modo, "o próprio funcionamento da troca abre espaço para o surgimento do dinheiro simbólico" (Itoh \& Lapavitsas, 1999, p. 44), visto que "o dinheiroouro é uma forma social adequada para expressar os valores das mercadorias; porém, ele (...) não se mostra apropriado para funcionar como meio de troca, isto é, como moeda" (Prado, s.d., p. 5).

Historicamente, então, no desempenho da sua função como meio de circulação, o dinheiro-ouro é progressivamente "substituído por símbolos ou signos de si mesmo" (Gorender, 1982: xv), como sejam moedas de metal não-precioso e, sobretudo, papelmoeda sem valor (Guerrero, 2010, p. 18-19). À semelhança do dinheiro áureo, o dinheiro simbólico é emitido pelo Estado (Itoh \& Lapavitsas, 1999, p. 44).

Deve notar-se que, como o próprio nome indica, o dinheiro simbólico funciona como um mero substituto, como um símbolo do valor do dinheiro áureo exclusivamente na função de meio de circulação (De Brunhoff, 1976, p. 36); "Sob a tutela do Estado, as notas e as moedas simbólicas podem circular e substituir a quantidade de ouro que teria sido requerida pela circulação" das mercadorias (Brewer, 1984, p. 32). É justamente por essa razão que o dinheiro circulante pode vir a ser algo completamente desprovido de valor: ele limita-se a representar ou expressar o valor do dinheiro real.

O fato a reter é que o dinheiro-ouro continua a desempenhar a função de medida do valor (e de padrão de preços), isto é, o dinheiro simbólico está ancorado no valor da mercadoria-dinheiro e pode ser convertido pelo seu detentor, em qualquer momento, na mesma. Por outras palavras, "para Marx, a natureza do dinheiro é determinada em primeira instância pelo seu papel como medida do valor, e apenas em segunda instância pela sua função como meio de compra" (Nelson, 1999, p. 91). Isto significa que "o papel do dinheiro como medida do valor é (...) predominante face ao seu papel de meio de circulação" (Nelson, 1999, p. 73). Felton Shortall sintetiza a relação entre as duas funções do dinheiro deste modo:

Na sua primeira função, o dinheiro está presente apenas como dinheiro ideal ou imaginário. Não é preciso que a mercadoria-dinheiro esteja presente na sua realidade material plena para que uma mercadoria expresse o seu valor intrínseco sob a forma do seu preço. Mas embora não seja preciso que o dinheiro esteja realmente presente, a atribuição de um preço à mercadoria pressupõe, não obstante, a existência real do dinheiro como uma materialização real do trabalho humano. Se o ouro não possuísse uma existência real, então as mercadorias seriam incapazes de expressar o seu valor numa quantidade nominal do seu peso. Todavia, agora, na sua função de meio de circulação, o dinheiro deve possuir uma presença real de modo a que o preço da mercadoria possa ser realizado; mas apenas necessita de estar presente enquanto símbolo ou substituto de si mesmo. Assim, a característica vital do dinheiro é agora a sua presença real, ao invés da sua existência real enquanto materialização do trabalho abstrato social. (Shortall, 1994, p. 231, itálico no original) 
Portanto, Marx estava perfeitamente ciente que

o dinheiro-ouro (...) não se mantém ao longo do tempo como o meio que intermedia efetivamente as trocas de mercadorias. (...) O ouro monetário mantém a propriedade de permutabilidade geral, mas ela se torna cada vez mais uma potência que nunca de fato se efetiva; na prática, ela passa a ser detida pelo dinheiro simbólico (...) na circulação de mercadorias. (Prado, s.d., p. 3)

Segundo Eleutério Prado, a identificação destas duas funções, sob a forma do ouro, no $1^{\circ}$ capítulo do Livro Primeiro de $O$ Capital resulta meramente do "modo de exposição" teórico de Marx (Prado, s.d., p. 3). No decurso da sua exposição, mormente no $3^{\circ}$ capítulo, as funções do dinheiro dissociam-se, espelhando a evolução empírica do dinheiro na sociedade capitalista: o ouro passa a desempenhar apenas o papel de medida dos valores, enquanto o dinheiro simbólico adquire o papel de meio de circulação (Prado, s.d., p. 3). O nó da questão é que a função de medida do valor - a pedra angular do sistema monetário moderno - tem, de acordo com Marx, de ser cumprida forçosamente pelo ouro ou por outra mercadoria-dinheiro com valor intrínseco, i.e., na qual foi despendido trabalho abstrato e socialmente necessário.

\subsubsection{A Determinação do Volume de Meio Circulante}

O valor das mercadorias e o valor da mercadoria-dinheiro são ambos determinados pelo tempo de trabalho socialmente necessário requerido pela sua produção, portanto, antes dos atos de troca que compõem a circulação (Shortall, 1994, p. 232-233). Neste sentido, "sendo o valor total das mercadorias uma grandeza predeterminada, é a grandeza do valor [das mercadorias] que necessita de ser circulado que determina a quantidade de dinheiro, com um certo valor, que circula" (Shortall, 1994, p. 233).

Na ótica de Marx, a "variação da quantidade total de dinheiro em circulação reflete os movimentos dos preços determinados pelos valores" (Jacobi, Bergmann \& MuellerJentsch, 1975, p. 111). O volume de meio circulante exigido pelo processo de circulação das mercadorias é, pois, "determinado pela soma dos preços" das mesmas (Marx, 1996a, p. 239). Assim, o volume de dinheiro circulante varia no mesmo sentido da soma dos preços a ser realizada: subindo caso esta aumente e descendo caso esta diminua (Marx, 1996a, p. 239). Se pressupusermos o volume das mercadorias como uma grandeza dada, a massa do dinheiro circulante acompanhará as flutuações dos seus preços (Marx, 1996a, p. 240).

Uma vez que a mesma peça monetária pode mediar a circulação de várias mercadorias num determinado intervalo temporal, o volume do dinheiro que funciona como meio circulante é dado pela razão entre a soma dos preços das mercadorias e o número de cursos das peças monetárias, i.e., a "velocidade de circulação":

$$
\text { Volume do dinheiro circulante }=\frac{\text { Soma dos preços das mercadorias }}{\text { Número de cursos das peças monetárias }}
$$


Deste modo, se a velocidade de circulação das peças monetárias crescer, o volume do dinheiro circulante diminuirá e vice-versa (Marx, 1996a, p. 242). A velocidade de circulação traduz a velocidade da mudança de forma das mercadorias, ou seja, a fluidez do entrelaçamento das metamorfoses das diferentes mercadorias. A velocidade aumenta se a complementaridade entre compra e venda ocorrer de fato, e diminui caso ambas se dissociem e autonomizem (Marx, 1996a, p. 242).

Vimos, no item anterior, que o ouro é progressivamente substituído pelo dinheiro simbólico - papel-moeda, por exemplo - como meio circulante. Apesar disso, "o papelmoeda (...) continua dependente da sua relação com o ouro. A lei específica da circulação de papel-moeda enuncia que: «a emissão de papel-moeda não deve exceder a quantidade de ouro (...) que circularia de fato caso não fosse substituída por símbolos»" (Jacobi, Bergmann \& Mueller-Jentsch, 1975, p. 112, itálico no original). Suzanne De Brunhoff partilha esta opinião: "o papel-moeda é apenas um símbolo do ouro e a sua circulação é, em última análise, regulada pela necessidade de dinheiro metálico" (De Brunhoff, 1976, p. 35-36).

Por exemplo, seja o padrão de preços dado pela equação 1 euro $=1 \mathrm{Kg}$ de ouro. Seja o valor da massa de mercadorias produzidas anualmente num certo país equivalente ao valor de $200 \mathrm{Kg}$ de ouro, nos quais estão cristalizadas, por hipótese, 20000 horas de trabalho socialmente necessário. Para facilitar o raciocínio, assumamos que cada peça monetária cumpre apenas um curso anual. Neste caso, para circular a massa de mercadorias produzidas será preciso um volume de meio circulante que represente $200 \mathrm{Kg}$ de ouro; dado o nosso padrão de preços, é preciso que o Estado emita 200 euros em papel-moeda (40 notas de 5 euros, por hipótese).

Existe a possibilidade de uma emissão excessiva de meio circulante face à massa de valor que ele deve simbolizar. O principal perigo da utilização do dinheiro simbólico sobretudo no caso do dinheiro fiduciário de curso forçado - como meio de circulação é o seu potencial inflacionário. Por exemplo, "se o Estado emitir demasiado papel-moeda em relação à quantidade de ouro que ele representa, o papel-moeda desvalorizar-se-á e o aumento dos preços absorverá as notas excedentárias" (De Brunhoff, 1976, p. 36). A inflação não decorre da utilização exclusiva do dinheiro fiduciário como meio de circulação, mas da sua emissão excessiva em relação às necessidades reais da economia.

\subsection{O Dinheiro como Dinheiro}

Pode concluir-se que "uma mercadoria converte-se em dinheiro enquanto é uma unidade de medida de valor e meio de circulação, ou, dito de outro modo, o dinheiro é a unidade de medida de valor e meio de circulação" (Marx, 1982, p. 92). O dinheiro como dinheiro, ou "dinheiro real", possui funções específicas: entesouramento, meio de pagamento e dinheiro mundial.

O entesouramento apenas é possível retirando o dinheiro da circulação, isto é, impedindo-o de dissolver-se na compra de bens e serviços. A criação de reservas monetárias desempenha um papel crucial na formação de capital latente - o investimento 
pressupõe normalmente a acumulação prévia de um montante mínimo de dinheiro - e no desenvolvimento do sistema de crédito moderno, i.e., na socialização das poupanças.

O desenvolvimento da circulação de mercadorias cria condições para que a sua venda e a realização do seu preço se dissociem temporalmente (Marx, 1996a, p. 254). O vendedor converte-se em credor e o comprador em devedor; nesta função o dinheiro surge como de meio de pagamento (Marx, 1996a, p. 255). Note-se que "a presença real do dinheiro é somente diferida" (Shortall, 1994, p. 241).

Nas transações internacionais o dinheiro tem de ser aceite universalmente, pelo que “o dinheiro mundial é puramente metálico" (Itoh \& Lapavistas, 1999, p. 51.), i.e., circula sob a forma de "barras de ouro" (Brewer, 1984, p. 33). Segundo Marx, na qualidade de dinheiro mundial o modo de existência do dinheiro adequa-se plenamente ao seu conceito como "forma universal do valor" (Shortall, 1994, p. 242):

\begin{abstract}
Ao sair da esfera interna de circulação, o dinheiro desprende-se das formas locais do padrão de preços, moeda, moeda divisionária e signo de valor, e reassume a forma originária de barras dos metais preciosos. (...) É só no mercado mundial que o dinheiro funciona plenamente como mercadoria, cuja forma natural é, ao mesmo tempo, forma diretamente social de realização do trabalho humano em abstrato. Seu modo de existir ajusta-se ao seu conceito (...). O dinheiro mundial funciona como meio geral de pagamento, meio geral de compra e materialização social absoluta da riqueza em geral (Marx, 1996a, p. 261-262).
\end{abstract}

Na prática, os fluxos de ouro entre países não-produtores de ouro, na época de Marx, traduziam normalmente a necessidade de consolidar a balança comercial e a balança de pagamentos (Brewer, 1984, p. 167). Os bancos centrais dos países que desejavam participar no comércio internacional eram obrigados a manter uma reserva de ouro para fazer face a eventuais saldos comerciais deficitários (Itoh \& Lapavitsas, 1999, p. 51). Conforme explica Paul Mattick, "uma vez que os débitos e os créditos dos diferentes países podem não se compensar mutuamente, os créditos residuais são saldados por transferências de ouro, de modo a conseguir uma balança de pagamentos equilibrada" (Mattick, 2010, p. 227-228).

\title{
3.5. A Relação Entre o Calor do Ouro e o Valor das Mercadorias
}

O preço das mercadorias nada mais é do que o seu valor de troca face ao ouro. Assim, antes de tudo, "os preços (...) podem subir ou cair devido a uma mudança do valor das mercadorias em causa ou em virtude de uma mudança do valor do ouro" (Brewer, 1984, p. 29). Há forçosamente uma décalage entre valor e preço, pois o valor de uma mercadoria apenas mudará se o tempo de trabalho socialmente necessário para produzi-la se alterar, mas o seu preço - o seu valor de troca - pode variar em virtude de uma alteração do tempo de trabalho socialmente necessário no ramo aurífero (De Brunhoff, 1976, p. 27).

As inúmeras combinações possíveis das variações do valor das mercadorias e/ou do valor do ouro estão descritas no Quadro 1 (cf. página seguinte). No caso específico da inflação, é preciso distinguir os efeitos do aumento da produtividade num ramo de produção de uma determinada mercadoria e no ramo da produção aurífera. No primeiro caso, o aumento da força produtiva do trabalho provoca a diminuição do valor unitário dessa 
mercadoria. No segundo caso, o aumento da força produtiva do trabalho provoca uma diminuição do valor do ouro, logo, um aumento simultâneo do valor de troca - do preçode todas as outras mercadorias, ceteris paribus.

\section{Quadro 1: Valor do Ouro e Valor das Mercadorias}

\begin{tabular}{|c|c|c|c|c|}
\hline & \multicolumn{3}{|c|}{ Valor do ouro } \\
\hline & & Diminui & Constante & Aumenta \\
\hline 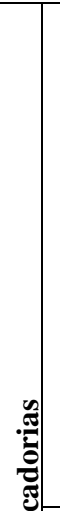 & 节 & $\begin{array}{l}\text { - Preços diminuem se o aumento da } \\
\text { produtividade no ramo das mercadorias for } \\
\text { superior ao do ramo aurífero; ou seja, se } \\
\text { diminuição do valor das mercadorias suplantar } \\
\text { diminuição do valor do ouro } \\
\text { - Preços constantes se o aumento da } \\
\text { produtividade nos dois ramos for idêntico; ou } \\
\text { seja, se a diminuição do valor das mercadorias } \\
\text { for idêntica à diminuição do valor do ouro } \\
\text { - Preços aumentam se o aumento da } \\
\text { produtividade no ramo aurífero for superior ao } \\
\text { do ramo das mercadorias; ou seja, se a } \\
\text { diminuição do valor do ouro suplantar a } \\
\text { diminuição do valor das mercadorias }\end{array}$ & $\begin{array}{c}\text { Preços } \\
\text { diminuem }\end{array}$ & Preços diminuem \\
\hline 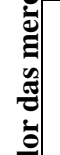 & 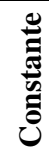 & Preços aumentam & $\begin{array}{c}\text { Preços } \\
\text { constantes }\end{array}$ & Preços diminuem \\
\hline$>$ & 丞 & Preços aumentam & $\begin{array}{c}\text { Preços } \\
\text { aumentam }\end{array}$ & $\begin{array}{l}\text { - Preços diminuem se o } \\
\text { aumento do valor do valor do } \\
\text { ouro for superior ao aumento } \\
\text { do valor das mercadorias } \\
\text { - Preços contantes se o } \\
\text { aumento do valor do ouro for } \\
\text { idêntico ao aumento do valor } \\
\text { das mercadorias } \\
\text { - Preços aumentam se o } \\
\text { aumento do valor das } \\
\text { mercadorias for superior ao } \\
\text { aumento do valor do ouro }\end{array}$ \\
\hline
\end{tabular}

Fonte: Adaptado, com algumas modificações, de Jacobi, Bergmann \& Mueller-Jentsch (1975, p. 110).

Assim, o aumento da produtividade provoca uma diminuição do tempo de trabalho socialmente necessário cristalizado em cada mercadoria, mas, no caso do ramo da produção de ouro, isso significa que uma dada unidade temporal (1 hora, 1 minuto, etc.) de trabalho passa a representar uma quantidade superior de ouro, logo, de dinheiro. A diminuição do valor do ouro significa que é preciso uma quantidade maior de ouro para adquirir a mesma quantidade de uma dada mercadoria (que contém o mesmo tempo de trabalho objetivado).

Portanto, o mesmo fator que contribui para a diminuição do valor unitário das mercadorias - o incremento da força produtiva do trabalho - contribui igualmente para $o$ aumento do seu valor de troca face ao ouro. Em suma, o efeito do aumento da 
produtividade do trabalho sobre o nível geral de preços depende do "resultado líquido" dos seus efeitos contrários no ramo aurífero e nos demais ramos de negócio:

a) Se o aumento da produtividade média do trabalho nos vários ramos que compõem a economia capitalista for superior ao aumento da produtividade no ramo da mineração aurífera, assistir-se-á a uma situação de descida generalizada do nível de preços provocada por alterações das relações de valor;

b) Se o aumento da força produtiva do trabalho no ramo da mineração aurífera for superior ao aumento da produtividade média do trabalho nos vários ramos que compõem a economia capitalista, assistir-se-á a uma subida generalizada do nível de preços provocada por alterações das relações de valor.

As teorias marxistas da inflação - que serão discutidas na secção 6 - não consideram este possível aumento dos preços em resultado da modificação do valor das mercadorias e/ou do ouro como inflação strictu sensu. Em termos marxianos, a inflação é um fenômeno puramente monetário, cingido à esfera da circulação, que traduz uma subida do nível geral de preços independente das relações de valor subjacentes (cf. Jacobi, Bergmann \& MuellerJentsch, 1975, p. 111).

\section{O Pressuposto da Teoria Monetária Marxiana e a sua Relevância Contemporânea}

O principal pressuposto da teoria monetária de Marx é que só uma mercadoriadinheiro, nomeadamente o ouro, é capaz de desempenhar a função de medida dos valores (cf. 3.1). Existe um consenso generalizado quanto ao fato de esta função ter sido cumprida pelo ouro até à abolição do padrão-ouro. As opiniões dividem-se quanto ao período pós- $2^{\mathrm{a}}$ Guerra Mundial, mas parece-me inequívoco que, no sistema de Bretton Woods, o ouro continua a ser a medida do valor porque todo o meio circulante, por intermédio do dólar estado-unidense, era conversível em ouro a uma taxa fixa. $\mathrm{O}$ dinheiro simbólico era um substituto do ouro.

As coisas complicam-se com o fim de Bretton Woods. A visão mais comum é que a teoria de Marx aplica-se somente "a um sistema monetário em que as notas bancárias eram conversíveis em ouro” (Brewer, 1984, p. 166). Marx estava ciente de que os vários países "substituem o dinheiro em grande medida, de um lado, por operações de crédito e, por outro, por dinheiro de crédito" (Marx, 1986, p. 48), mas assevera, de fato, que a reserva metálica do banco central, especialmente na medida em que garante a conversibilidade das diversas figuras monetárias em ouro, é o "eixo de todo o sistema de crédito" (Marx, 1986, p. 92). Na sua ótica, o "dinheiro de crédito só é dinheiro na medida em que, no montante de seu valor nominal, representa absolutamente o dinheiro real” (Marx, 1986, p. 48).

Assim, "o dinheiro - na forma dos metais preciosos - constitui a base da qual o sistema de crédito, pela própria natureza, nunca se pode desprender" (Marx, 1986, p. 116). $\mathrm{Na}$ sua época, isso era evidente durante as crises cíclicas que despoletavam uma autêntica corrida ao ouro: "Na crise surge a exigência de que todas as letras, papéis de crédito e 
mercadorias sejam conversíveis, de uma vez e simultaneamente em dinheiro bancário, e todo esse dinheiro novamente em ouro" (Marx, 1986, p. 93).

Como é sabido, hoje em dia esta conversibilidade oficial do dinheiro já não existe. Porém, embora os Estados não garantam a conversibilidade dos signos monetários em ouro, isso não significa que a conversibilidade se tenha tornado impossível nem, mais importante ainda, que o ouro tenha cessado por completo de desempenhar a função de medida dos valores. Anitra Nelson relembra que, em Marx, "a conversibilidade das notas bancárias (...) é «uma lei econômica independentemente do que as normas jurídicas possam dizer»" (Nelson, 1999, p. 83). Anwar Shaikh, por sua vez, salienta que

Os termos «conversível» e «inconversível» são completamente enganadores, porque o dinheiro funcionante é sempre conversível em ouro. As chamadas moedas conversíveis assentam na promessa de conversão do dinheiro em ouro a uma taxa fixa estabelecida (...) pela autoridade monetária, enquanto as chamadas moedas inconversíveis assentam na possibilidade de conversão do dinheiro em ouro a uma taxa flexível determinada no mercado aurífero. (Shaikh, 2016, p. 192-193)

Deste modo, a única coisa que mudou foi que o dinheiro fiduciário deixou de ser conversível em ouro a uma taxa de câmbio fixa oficial, sancionada pelo Estado (Shaikh, 2016, p. 185); mas a conversão continua a ser possível nos mercados apropriados. Para além disso, "em tempos atribulados, o ouro assume-se" ainda "como o refúgio derradeiro" do dinheiro (Shaikh, 2016, p. 185).

David Harvey observa que "a relação do dinheiro com o trabalho socialmente necessário (...) tornou-se cada vez mais remota e elusiva. Mas dizer que ela é oculta, remota e elusiva não significa que ela não exista" (Harvey, 2010, p. 70). Em suma, "os metais preciosos, mercadorias com valor intrínseco, permanecem em última instância o único equivalente universal" válido (Mandel, 1971, p. 257).

O ouro retém a sua função de medida do valor porque "somente trabalho objetivado pode portar tal função. Signo de valor não é forma de valor" (Barbosa, 2010, p. 156). A mesma ideia é defendida por Eleutério Prado: "a medida do valor depende crucialmente do quantum de trabalho abstrato e socialmente necessário para produzir a mercadoria ouro" (Prado, s.d., p. 6), ou seja, a função de medida dos valores tem de ser forçosamente desempenhada por um dinheiro com valor intrínseco, i.e., uma mercadoria-dinheiro. ${ }^{3}$

\section{A Inflação: Breve Resumo Histórico}

Durante o século XIX, a maior parte das nações utilizava "padrões monetários metálicos", nomeadamente o chamado padrão-ouro (Mattick, 2010, p. 221). Devido aos enormes custos associados à circulação do dinheiro-ouro, a função de meio de circulação era largamente desempenhada, já nessa altura, por dinheiro simbólico (Mattick, 2010, p. 223). Todavia, "o papel-moeda em circulação funcionava como um representante do ouro"

\footnotetext{
${ }^{3}$ Embora esta função seja, hoje em dia, desempenhada de modo eminentemente problemático (cf. 6.2.4).
} 
(Heinrich, 2012, p. 69), de tal maneira que o papel-moeda emitido pelos bancos centrais era oficialmente conversível em ouro (Heinrich, 2012, p. 69).

Neste sentido, os bancos centrais eram obrigados a deter reservas consideráveis de ouro para fazer face aos eventuais pedidos de conversão do dinheiro simbólico em dinheiro áureo (Heinrich, 2012, p. 69). Este lastro físico em ouro restringia a emissão do papelmoeda, que não podia ser arbitrária, e almejava, assim, prevenir a sua depreciação (Mattick, 1978, p. 63).

Não era só ao nível doméstico que a mercadoria-dinheiro ocupava uma posição privilegiada. O padrão-ouro regulava também o comércio internacional, conforme explica Paul Mattick:

A preferência marcada pela moeda-mercadoria (...) teve o seu alargamento internacional e a sua fundamentação mais importante no «automatismo» do padrão-ouro como regulador das trocas internacionais. Através da fixação do preço do ouro, o padrão-ouro ligava os valores das várias unidades de conta monetárias nacionais entre si e aos seus valores ouro. Um dólar representava uma certa quantidade de ouro, tal como a libra inglesa e as outras divisas ligadas ao padrão-ouro. Se a cotação da libra fosse quatro dólares, isso significava que o conteúdo em ouro de uma libra equivalia ao de quatro dólares. (Mattick, 2010, p. 227)

Neste sistema monetário, "se o débito e crédito das transações internacionais de uma nação não se compensassem, os déficits da balança de pagamentos eram saldados através de remessas de ouro", ou seja, "o ouro fluía dos países com balança de pagamentos negativa para os países com balança de pagamentos positiva" (Mattick, 1978, p. 64).

A $1^{\text {a }}$ Guerra Mundial abalou fortemente o padrão-ouro, na medida em que, confrontados com dificuldades, "os Estados endividavam-se e emitiam moeda sem terem em conta as suas reservas de ouro" (Mattick, 2010, p. 229). Para além disso, a inflação foi utilizada como arma para saldar as enormes dívidas acumuladas durante a guerra (Mattick, 2010, p. 229). O padrão-ouro acabaria por ser abandonado definitivamente na sequência da Grande Depressão de 1929:

[A] partir de 1929, ficou claro que o sistema econômico capitalista (...) não podia se recuperar das crises exclusivamente por meio de sua própria força. (...) A recuperação, por isso, passou a exigir a intervenção do Estado (...). A política econômica ativa, isto é, o manejo da política fiscal e monetária para promover a acumulação de capital, tornou-se incompatível com a manutenção do padrão-ouro (Prado, 2016, p. 8).

O primeiro país a abolir o padrão-ouro foi a Grã-Bretanha, em Setembro de 1931, despoletando decisões similares em outras nações. Eleutério Prado salienta que o período de vigência do padrão-ouro - cerca de 230 anos - foi marcado por uma estabilidade dos níveis de preços, sobretudo nas duas principais economias mundiais: a inglesa e a estadounidense (Prado, s.d., p. 9). Anwar Shaikh partilha esta visão, apresentando evidências empíricas que comprovam que, desde 1780 até 1940, "os países capitalistas conheceram ondas sucessivas de subidas e quedas de preços", sem que seja identificável uma tendência inequívoca de longo prazo (cf. Shaikh, 2016, p. 63).

Assim, a inflação permanente é um fenômeno recente, característico do período pós$2^{a}$ Guerra Mundial: "os níveis de preços começam a revelar um novo padrão, em que que 
crescem interminavelmente" (Shaikh, 2016, p. 63). O abandono do padrão-ouro acarretou o fim da relativa estabilidade dos preços, assistindo-se ao "arranque de um persistente processo inflacionário" (Prado, s.d., p. 9).

No final da $2^{\text {a }}$ Guerra Mundial, o ouro foi remetido para um papel exclusivo nas transações internacionais. As novas regras de funcionamento do sistema monetário internacional foram estabelecidas com a celebração do Acordo de Bretton Woods, em Julho de 1944. O dólar estado-unidense foi definido como a moeda-padrão mundial e como a única divisa que conserva a sua conversibilidade em ouro, à taxa fixa de 35 dólares por onça de ouro (Shaikh, 2016, p. 185). As paridades das outras moedas estavam diretamente indexadas ao valor do dólar, normalmente com taxas de câmbio fixas, que desempenhava o papel de moeda de reserva internacional (Mattick, 1978, p. 47).

Conforme já foi mencionado, "o boom do pós-guerra foi acompanhado por uma inflação lenta e persistente (creeping inflation), embora assimétrica, desde o seu início" (Mattick, 1978, p. 43). O crescimento económico dos "Trinta Gloriosos" foi enquadrado por uma intervenção estatal sem precedentes, a que não foi alheio o triunfo ideológico do keynesianismo. O Estado procurou "estimular a atividade econômica através da expansão do crédito (...) e do déficit orçamentário" (Mattick, 2010, p. 233), portanto, mediante a adoção de "políticas monetárias inflacionistas” (Mattick, 1978, p. 43).

A isto juntou-se o aumento do endividamento privado - tanto das empresas como das famílias. Em suma, houve um "crescimento inaudito da massa de signos monetários" sem valor (Thomas, 1999, p. 99), de tal modo que, "no final dos anos 60, ficou patente que a quantidade massiva de dólares em circulação tinha tornado uma ficção o acoplamento do dólar ao ouro" (Heinrich, 2012, p. 70).

A década de 1970 trouxe a estagnação económica e o aumento do desemprego conjugados com a inflação, fenômeno que ficaria conhecido como estagflação. Tornou-se claro, finalmente, que "a natureza suscetível a crises do capitalismo não podia ser eliminada por intervenções do Estado na economia” (Mattick, 1978, p. 24-25). Em 1971, o presidente estado-unidense Richard Nixon suspendeu a conversibilidade do dólar em ouro e, em 1973, o primeiro choque petrolífero deu a estocada final no sistema monetário de Bretton Woods. A partir de 1973, assistiu-se à "criação de um sistema nacional e internacional de dinheiro fiduciário puro" (Reuten, 2003, p. 45).

Apesar de ter cessado a sua conversibilidade em ouro, o dólar estado-unidense, na qualidade de divisa da potência económica e militar hegemônica, continua a funcionar largamente como reserva de muitos bancos centrais, mesmo tratando-se de um dinheiro fiduciário sem valor. $\mathrm{O}$ dólar continuou igualmente, nas últimas décadas, a desempenhar a função de dinheiro mundial que intermedeia uma parte substancial do comércio internacional: "o surgimento de um sistema de crédito global, baseado na economia e território das potências dominantes, conferiu ao dinheiro de crédito de uma nação particular a função de dinheiro mundial" (Itoh \& Lapavitsas, 1999, p. 51).

Todavia, parece existir uma tendência para a "desmaterialização" definitiva do dinheiro (Lipietz, 1979, p. 107), i.e., para uma situação em que "as mercadorias circulam" praticamente "sem dinheiro" físico, mediante o recurso a cartões de débito e de crédito e a 
dinheiro eletrônico, no caso dos particulares, e aos "direitos de saque especiais entre nações" (Lipietz, 1979, p. 105).

O fim de Bretton Woods abriu uma autêntica Caixa de Pandora: o advento do dinheiro fiduciário de curso forçado implicou o desaparecimento de quaisquer limites formais à emissão monetária (Thomas, 1999, p. 98). Com a desregulação promovida pelo capitalismo neoliberal, a emenda foi pior do que o soneto: a estagnação económica apenas foi superada artificialmente, à custa de níveis de envidamento e da multiplicação de capital fictício que desafiam todos os limites da imaginação.

Foi erigida uma superestrutura financeira colossal onde o capital simula a sua acumulação através da insuflação e rebentamento de bolhas especulativas sucessivas. Não só o pleno emprego desapareceu definitivamente, como o desemprego se mantem permanentemente elevado, atestando a falta de rentabilidade da economia real.

No que se refere ao comportamento dos níveis de preços, Geert Reuten identifica vários períodos distintos ao longo do século XX: “i) por volta da $1^{\mathrm{a}}$ Guerra Mundial: inflação galopante; ii) 1920-35: deflação; ${ }^{4}$ iii) por volta da $2^{\text {a }}$ Guerra Mundial: inflação galopante; iv) 1948-73: inflação lenta mas persistente; v) 1973-79: inflação galopante; vi) 1979-2000: inflação lenta mas persistente" (Reuten, 2003, p. 44-45). Importa reter que no período pós- $2^{\mathrm{a}}$ Guerra Mundial, pela primeira vez na história do modo de produção capitalista, "os preços subiram de modo mais ou menos contínuo", que pode ser caracterizado de "inflação permanente" (Shaikh, 2016, p. 188).

Muitos países, sobretudo no chamado Terceiro Mundo, enfrentam regularmente situações de hiperinflação. Todavia, mesmo no caso das potências econômicas, o aumento cumulativo dos preços não deixa de ser avassalador. Anwar Shaikh faz notar o seguinte acerca dos EUA e do Reino Unido:

\begin{abstract}
[A] taxa média anual de inflação nos EUA, no período de sessenta e oito anos compreendido entre 1940 e 2008, foi de apenas 3,96\%. Isto parece reconfortante até pararmos para pensar que o nível de preços cresceu, desse modo, mais de catorze vezes desde o seu valor inicial (i.e., cresceu $1302 \%$ ao longo de sessenta e oito anos). O padrão [de inflação] no Reino Unido foi ainda pior: uma taxa média de inflação de 5,6\% e um nível de preços que cresceu mais de 39 vezes face ao seu valor inicial. (Shaikh, 2016, p. 180)
\end{abstract}

A situação de inflação permanente significa, ainda, que as crises periódicas, associadas ao ciclo econômico, adquiriram uma nova configuração. Ao contrário das crises típicas do passado, os períodos de recessão econômica deixaram de ser acompanhados por um declínio dos preços (Mandel, 1976, p. 418). Paul Mattick relembra que, até ao século XX, as crises eram superadas após uma "depressão deflacionista" (Mattick, 1978, p. 30), ou seja, a deflação temporária era consensualmente admitida como uma forma de restaurar o equilíbrio temporário da economia capitalista (Mattick, 1978, p. 30).

Todavia, este consenso começou a mudar à medida que as contradições do modo de produção capitalista se agravaram, sobretudo após a Grande Depressão de 1929 (Mattick,

\footnotetext{
${ }^{4}$ Trata-se de uma média dos vários países, porque houve hiperinflação na Alemanha após a $1^{\text {a }}$ Guerra Mundial, por exemplo.
} 
1978, p. 30). Assim, “a política intervencionista [do Estado] procurou [doravante] atingir por meios inflacionistas o que já não parecia ser alcançável através de métodos deflacionistas" (Mattick, 1978, p. 31).

\section{Teorias Marxistas da Inflação}

Existem três tipos fundamentais de teorias marxistas da inflação: i) A teoria do capital monopolista entende a inflação como o resultado da imposição de preços de monopólio substancialmente superiores ao valor produzido; ii) A teoria da emissão excessiva de meio circulante atribui a inflação à criação desmesurada de signos monetários; iii) A teoria do conflito distributivo defende que a inflação é o resultado da luta entre capital e trabalho assalariado e, em especial, uma arma para contrariar a queda da taxa de lucro. Estas teorias serão expostas nos itens seguintes.

\subsection{Teoria do Capital Monopolista}

A teoria do capital monopolista atribui a inflação à possibilidade de as grandes empresas - tendencialmente monopolistas - se servirem da capacidade acrescida de criação monetária dos bancos para aumentarem os seus preços. Por outras palavras, o sistema monetário e creditício emite signos monetários adicionais adequados às necessidades do capital monopolista, permitindo-lhe realizar preços de venda mais elevados. A emissão monetária é, de certo modo, instrumentalizada pelo capital monopolista.

Ernest Mandel, um dos principais proponentes desta teoria, defende que

"a estrutura da desvalorização monetária pode ser exposta do seguinte modo: (...) A transição de um padrão-ouro (...) para um sistema monetário que garante ao capital monopolista a quantidade de dinheiro adequada às suas necessidades, através da criação de dinheiro bancário, permite que as grandes empresas capitalistas, sob as condições de um controle relativo do mercado (concorrência oligopolista, liderança de preço), aumentem ligeiramente os preços de venda das suas mercadorias em períodos de crescimento econômico e os estabilizem durante as recessões. Dado o aumento enorme da produtividade do trabalho ligado à terceira revolução tecnológica, isto implica um aumento das suas margens de lucro (...) que conduz a «preços administrados»”". (Mandel, 1976, p. 429, itálico no original)

Assim, "a força motriz da inflação é constituída pelas grandes empresas e pela sua capacidade de utilizar a expansão do dinheiro de crédito para obter a curto prazo o volume de dinheiro requerido para as suas projeções de acumulação e realização" (Mandel, 1976, p. 437). Os aumentos dos preços são sempre compensados por um "aumento adequado da quantidade de dinheiro" circulante (Mandel, 1976, p. 430). Quanto maior for o grau de monopolização da economia, tanto maiores serão os preços de mercado praticados (Mandel, 1976, p. 431).

Segundo Mandel, o papel da inflação jaz "na ocultação da redução dos valores das mercadorias, na facilitação da acumulação de capital, no disfarce do aumento da taxa de exploração e na resolução temporária das dificuldades de realização através da extensão do crédito" (Mandel, 1976, p. 437). Todavia, a estratégia inflacionista do capital monopolista 
enfrenta "limites intransponíveis": a partir de um certo limiar, "a inflação lenta mas persistente deixa de cumprir a sua função ou converte-se em inflação galopante" (Mandel, 1976, p. 437).

\subsection{Teoria da Emissão Excessiva de Meio de Circulação}

\subsubsection{David Harvey: o Papel do Banco Central no Fenômeno Inflacionista}

O banco central é o "ápice da pirâmide do sistema de crédito" (Barbosa, 2010, p. 159). Quando o sistema monetário já não está oficialmente ligado à mercadoria áurea, "os bancos centrais «criam» o dinheiro real" (Heinrich, 2012, p. 161), ou seja, detêm o monopólio de emissão monetária cuja validade é "incontestável” (Lipietz, 1979, p. 109). Uma vez que deixaram de assegurar a sua conversibilidade em ouro, os bancos centrais limitam-se a declarar que o dinheiro simbólico que emitem possui qualidades idênticas às do ouro; estamos perante um dinheiro de curso forçado, criado ex nihilo (Lipietz, 1979, p. 109). O nó da questão é que os bancos centrais não enfrentam nenhum "limite formal no que se refere à criação monetária" (Heinrich, 2012, p. 161).

Neste contexto, a oferta monetária do banco central pode não estar em harmonia com a produção real de valor na economia no seu conjunto (Harvey, 2006, p. 294) e, assim, de acordo com David Harvey, ser uma potencial fonte de inflação: "se a moeda nacional não for conversível em ouro, então um banco central pode, com efeito, imprimir dinheiro (...). Ao fazê-lo, contudo, desvaloriza o próprio dinheiro" (Harvey, 2006, p. 295).

Na ótica de Harvey, todo o crédito - na qualidade de antecipação de ganhos futuros - é capital fictício, que ainda carece de ser validado socialmente através da produção e acumulação reais (Harvey, 2006, p. 295). O problema surge quando este capital fictício não é validado pela produção ulterior de valor, mormente durante uma crise cíclica de sobreacumulação (Harvey, 2006, p. 295). A inflação decorre da mudança fundamental da resposta dos bancos centrais às crises da economia capitalista.

$\mathrm{Na}$ época de Marx, a crise despoletava uma corrida à liquidez, i.e., um estado de coisas em que o ouro era (temporariamente) o único meio de troca aceite (Harvey, 2006, p. 294). Era exigido que toda a riqueza produzida - a massa de mercadorias - fosse validada socialmente através do seu intercâmbio por dinheiro real - por ouro. Visto que as exigências de conversibilidade das várias formas de dinheiro em ouro excediam largamente a reserva de metal precioso disponível, isso traduzia-se numa queda abrupta do preço das mercadorias, portanto, numa situação de deflação (Harvey, 2006, p. 294), que criava as condições para um novo ciclo de retomada.

Ora, hoje em dia, a atuação do banco central face a uma crise é bastante diferente. $\mathrm{O}$ seu intuito é evitar a desvalorização brutal das mercadorias, pelo que, para combater a crise, é forçado a "imprimir dinheiro de curso forçado para comprar os excedentes e realizar os valores dos capitais fictícios" (Harvey, 2006, p. 295). A queda da taxa de lucro pode ser minorada através de uma emissão monetária que permite incrementar os preços: "Se o 
Estado resolver (...) expandir a oferta monetária (...), então os capitalistas individuais podem estabilizar as suas taxas de lucro, em meio à queda da produção de mais-valia, simplesmente através do ajustamento dos preços das mercadorias" (Harvey, 2006, p. 313).

Na ótica de Harvey, "a inflação (...) possui raízes mais profundas na transformação geral da desvalorização das mercadorias em desvalorização do dinheiro" (Harvey, 2006, p. 313). Em suma, "defender o valor nominal das mercadorias em que está corporizado trabalho socialmente desnecessário" assume-se como uma política monetária "irracional" que pode conduzir, em última instância, à "inflação galopante" (Harvey, 2006, p. 295, itálico no original). Ao validar socialmente uma massa considerável de trabalhos privados despendidos e, desse modo, ao realizar artificialmente os preços das mercadorias - uma massa de valor fictício -, o banco central contribui diretamente para a subida do nível geral de preços.

\subsubsection{Paul Mattick: Queda da Taxa de Lucro e Despesa Pública como Origens da Inflação}

Na perspectiva de Paul Mattick, o problema de fundo da economia capitalista é a queda tendencial da taxa de lucro, "que pressiona o aumento dos preços" (Mattick, 1978, p. 26); ou seja, "cada capital individual, no interior de um país, procura impiedosamente manter e aumentar o seu quinhão de uma mais-valia social total em contração através de aumentos dos preços" (Mattick, 1978, p. 26).

Cabe ao Estado, através da expansão da "oferta de moeda e de crédito" (Mattick, 2010, p. 231) e dos "gastos públicos financiados pelo déficit orçamentário" (Mattick, 1978, p. 37) providenciar os meios para a realização desses preços artificialmente mais elevados. Por outras palavras, é fulcral a existência de uma "política monetária acomodatícia" (Reuten, 2003, p. 51). Esta foi justamente a lógica subjacente à ascensão do keynesianismo, sobretudo durante os "Trinta Gloriosos": assistiu-se à adoção generalizada do deficit spending, i.e., de políticas massivas de investimento público com vista a estimular a “demanda monetária efetiva" (Mandel, 1976, p. 417).

Mattick refere ainda a "influência inflacionista da produção não lucrativa induzida pelo Estado" (Mattick, 1978, p. 18). Portanto, para além de realizar os preços anormalmente acrescidos, a despesa pública estimula ficticiamente o nível de produção: "a produção continua, apesar da falta de rentabilidade, por via da expansão do crédito" e da despesa públicos (Mattick, 2010, p. 242). O Estado absorve - e valida socialmente - o output de uma vasta panóplia de atividades improdutivas em termos capitalistas.

Em suma, "a inflação é uma expressão da insuficiência dos lucros que deve ser ultrapassada através de políticas monetárias" (Mattick, 1978, p. 21). O Estado procura contrariar a quebra da rentabilidade do capital através de uma política monetária expansionista (Mattick, 1978, p. 74). Essa rentabilidade é, em muitos casos, mantida artificialmente na ausência de uma verdadeira acumulação de capital; não há um aumento do valor e da mais-valia produzidos, mas apenas dos preços de mercado sob a forma de 
inflação. Multiplicam-se os "lucros fantasma derivados mais da inflação do que da produção" de mais-valia (Mattick, 1978, p. 55).

Todavia, esta situação acaba por conduzir a um beco sem saída se a lucratividade do setor privado não for restaurada, como provaram empiricamente o fim dos "Trinta Gloriosos", o esgotamento das políticas keynesianas e o advento desastroso da estagflação, cujos consequências nefastas perduram até aos dias de hoje. Em última instância, "a taxa de inflação crescente (...) revelou-se (...) incapaz de evitar uma queda dos lucros reais. Políticas monetárias e creditícias expansionistas apenas elevaram os preços sem conseguirem aumentar significativamente a produção" (Mattick, 1978, p. 25).

A lição dolorosa que deve ser retirada, na opinião de Mattick, é que "as políticas (...) inflacionistas do Estado são menos medidas tomadas para controlar a economia do que reações a processos que já estão fora de controle" (Mattick, 1978, p. 46). A reprodução ampliada da economia capitalista é algo que "não depende da massa monetária, mas da rentabilidade do capital" (Mattick, 2010, p. 236).

\subsubsection{Tom Thomas: o Crédito Privado como Raiz da Inflação}

Através do sistema de reservas fracionárias, os bancos privados adquirem o poder de criar dinheiro "a partir do nada" (Shaikh, 2016, p. 181). Nesta faceta, "o crédito é uma criação privada de dinheiro. (...) [O]s bancos (...) emprestam dinheiro que eles mesmos criam" (Thomas, 2009, p. 34, itálico nosso). O crédito privado engloba os empréstimos concedidos pelo sistema bancário: i) Às empresas, com vista ao financiamento do seu processo de produção; ii) Às famílias, para financiar o consumo de bens duradouros; iii) Ao público em geral, para financiar operações especulativas nos mercados financeiros.

Tom Thomas argumenta que "o crédito, na qualidade de criação monetária privada, é um poderoso fator de inflação", ou seja, "de aumento dos preços nominais" das mercadorias (Thomas, 2009, p. 31). Por outro lado, o crédito privado contribui diretamente para a "inflação da massa financeira", ou seja, da "quantidade e preço dos títulos financeiros" (Thomas, 2009, p. 31). O efeito inflacionista do crédito decorre da exterioridade do dinheiro enquanto figura do valor (Thomas, 2009, p. 30):

A exterioridade do dinheiro devém autonomia, plenamente realizada com o sistema de crédito, em que, embora seja suposto representar sempre o valor, o dinheiro cresce independentemente da valorização real, da produção real de valor. Desenvolve-se assim necessariamente uma contradição entre este crescimento (...) da massa monetária e aquele do valor que o dinheiro é suposto representar. (Thomas, 1999, p. 116)

Por conseguinte, a "independência formal do dinheiro relativamente às mercadorias" (Thomas, 2009, p. 30) é potenciada pelo sistema de crédito e significa que "pode ser emitida uma quantidade quase ilimitada" de dinheiro pelos bancos, sobretudo "quando se trata de dinheiro fiduciário ou escritural" (Thomas, 2009, p. 30). Neste contexto,

se é emitido mais dinheiro que aquele correspondente aos valores produzidos e trocados, isto é, se a massa monetária em circulação aumenta mais do que aquela dos valores trocados, então a 
unidade monetária já não representa mais o mesmo valor. Estamos perante o fenômeno bem conhecido da inflação monetária. (Thomas, 2009, p. 30)

Em suma, "o crescimento da massa monetária induzido pelo crescimento do crédito produz uma inflação considerável" (Thomas, 2009, p. 42), mas, segundo Thomas, esse efeito é atenuado porque a inflação se repercute, por enquanto, mais nos "preços dos ativos financeiros e imobiliários" do que nos "preços dos bens de consumo" (Thomas, 2009, p. 42). Todavia, "um sistema de produção que apenas se pode reproduzir através do aumento incessante de uma massa monstruosa de endividamento (...) acabará, evidentemente, por ruir como um castelo de cartas" (Thomas, 2009, p. 25).

\subsubsection{Eleutério Prado: o Dinheiro Fictício}

Eleutério Prado começa por observar que a função de "medida do valor (...) requer o dinheiro-ouro para ser expressa" (Prado, 2013, p. 141), pois "admitir que o dinheiro-papel atue como medida de valor no campo da realidade econômica equivale a supor, no campo da realidade natural, que algo que não tem peso possa servir como medida do peso" (Prado, 2013, p. 137). O dinheiro seria incapaz de "se sustentar no mundo atual se não tivesse uma relação de equivalência implícita com o ouro" (Prado, 2013, p. 140, itálico no original).

Todavia, na ótica do autor, a função de medida dos valores torna-se progressivamente problemática num contexto em que o dinheiro simbólico adquire uma autonomia sem precedentes (Prado, 2013, p. 141-142). A função de medida dos valores "foi sendo (...) recalcada no correr do processo histórico" capitalista (Prado, s.d., p. 7), assistindo-se a "uma inversão (...) na ordem da representação: o dinheiro-papel deixa de figurar como signo do ouro para se transformar em dinheiro de curso forçado cuja contrapartida é um débito impagável do Estado" (Prado, 2013, p. 142). Desta maneira, o dinheiro fiduciário contemporâneo já não é um mero signo do ouro, mas algo que "possui personalidade social própria" (Prado, 2013, p. 141).

$[\mathrm{N}]$ o capitalismo de hoje, o dinheiro-papel não se apresenta mais como signo do ouro. Ele se tornou (...) dinheiro que além de não portar trabalho abstrato e não ter, portanto, conteúdo de valor já posto, não representa também o conteúdo de valor já posto de um dinheiro-mercadoria, ao qual substituiria na circulação de mercadorias. (Prado, 2016, p. 10)

Trata-se de um dinheiro que apenas é capaz de representar precariamente o valor do ouro através de mediações cada vez mais complexas com o mercado dessa commodity:

[O] valor fictício do dinheiro-papel oficialmente inconversível está (...) numa relação de equivalência - que se impõe tendencialmente por meio de flutuações sempre que a emissão não seja excessiva - com o valor real do ouro, por meio do mercado de ouro. Assim se explica como o dinheiro (...) inconversível, mesmo «não» sendo valor, é capaz de mediar a mensuração do valor. Eis que ele representa valor por meio de uma equivalência complexa com o valor do ouro. $\mathrm{O}$ dinheiro fictício é uma forma que adere a um material, o papel-moeda, que funciona como uma mercadoria virtual. $\mathrm{O}$ seu «valor» é socialmente válido, mesmo se não contém qualquer átomo da substância trabalho. A validade social desse valor, entretanto, é colocada em questão nos processos inflacionários que se tornaram endêmicos nas economias capitalistas contemporâneas. (Prado, 2013, p. 143-144, itálico nosso) 
De acordo com Prado, o dinheiro é, hoje em dia, um "dinheiro fictício" (Prado, 2016, p. 10, itálico nosso), i.e., "uma forma de valor que «não» possui valor, mas o representa de algum modo" (Prado, 2013, p. 139). O autor preconiza, então, que o ouro ainda constitui, indireta e fragilmente, a medida dos valores, pois ainda existe uma ligação residual do dinheiro com o mercado de ouro. Contudo, por outro lado, essa ligação remanescente não assegura o cumprimento pleno da função de medida dos valores, pelo que o dinheiro é um dinheiro fictício predisposto para a desvalorização sempre que essa relação problemática com o mercado aurífero é (inter)rompida: "Se essa relação implícita desaparecer, ele vira fumaça, assim como vira fumaça uma ação (capital fictício) que representa um capital real que foi inteiramente queimado pelo fogo" (Prado, 2013, p. 144).

Prado conclui que a ascensão do dinheiro fictício - e da correspondente inflação permanente - está intimamente associada à mudança da configuração do modo de produção capitalista ao longo do século XX. As dificuldades estruturais de acumulação de capital na esfera industrial real conduziram a uma deslocação gradual do capital para a esfera financeira, onde simula a sua acumulação através da criação de bolhas gigantescas de capital fictício (Prado, 2016, p. 7).

Tal como o capital industrial perdeu a sua preponderância, também a base metálica aurífera deixou de ser um sustentáculo adequado do sistema de crédito e do novo regime de acumulação híper-dependente do capital fictício: "Ao invés de ancorar o sistema de crédito no sistema monetário do ouro e, assim, no trabalho posto já como valor, passou-se a ancorá-lo no trabalho a ser realizado, ou seja, numa representação de valor futuro" (Prado, 2016, p. 9). O dinheiro de crédito é o instrumento que possibilita a expansão incessante dos signos monetários requeridos pelo capital fictício.

\subsection{Teoria do Conflito Distributivo}

De acordo com a teoria do conflito distributivo, a inflação resulta da luta entre a classe capitalista e a classe operária pela partilha do valor criado (Jacobi, Bergmann \& Mueller-Jentsch, 1975, p. 121). Em concreto, a inflação assume-se como uma arma ao serviço da classe capitalista que procura travar a queda da taxa de lucro através da compressão dos salários reais (Barbosa, 2010, p. 160); "um aumento geral dos preços, acompanhado por um crescimento mais lento dos salários, conduz ao aumento dos lucros" (Mattick, 1978, p. 37).

Paul Mattick explica o funcionamento deste mecanismo compensatório da seguinte forma:

[Q]uando há inflação, os salários aumentam mais lentamente do que os preços de outras mercadorias. (...) Os preços das mercadorias são fixados depois de os custos de mão-de-obra incorporados neles terem sido estabelecidos ou pagos. Por conseguinte, um aumento dos salários não pode impedir um aumento ainda mais rápido dos preços das mercadorias, pelo que o custo do trabalho relativamente às mercadorias que produz terá de diminuir. (...) Uma vez que o movimento dos salários é mais lento do que o dos preços das mercadorias, a inflação conduz a um aumento dos lucros. (Mattick, 2010, p. 235)

Deste modo, 
a distribuição do produto social entre capital e trabalho deve ser alterada para assegurar a lucratividade do capital. Se os preços crescerem mais rapidamente do que os salários, então aquilo que não pode ser extraído dos trabalhadores na produção é-lhes retirado no processo de circulação. Isto é simultaneamente a causa e a consequência da expansão monetária e creditícia, de modo que um crescimento inflacionário dos lucros aparece como uma aceleração da inflação [dos preços]. (Mattick, 1978, p. 19-20)

Ernest Mandel salienta que “a inflação possui, assim, (...) uma dupla função: permite aumentar a taxa de mais-valia e simultaneamente ocultar a queda da parcela relativa dos salários através do aumento dos salários nominais" (Mandel, 1976, p. 422n37). Todavia, se, aparentemente, "a taxa de lucro nominal é aumentada através da inflação" (Lipietz, 1985, p. 113), Alain Lipietz relembra que a subida do preço dos componentes do capital constante provoca o aumento da composição orgânica do capital, tornando cada vez mais onerosa a reposição das matérias-primas consumidas e dos equipamentos depreciados (Lipietz, 1985, p. 113).

\section{Inflação: Alguns Dados Empíricos}

Embora as teorias marxistas da inflação apresentadas na secção 6 não deem, regra geral, uma atenção especial a esse aspecto, viu-se em 3.5 que a subida do nível geral dos preços pode resultar da desvalorização da medida do valor (na prática, da queda do valor do ouro). ${ }^{5}$ Assim, em primeiro lugar, é preciso investigar a relação empírica que se estabeleceu entre o valor do ouro e o valor das demais mercadorias ao longo do século XX, porquanto o "movimento fundamental dos preços no longo prazo está relacionado com as dinâmicas distintas da produtividade social (...) do trabalho nos diversos ramos de negócio, por um lado, e na indústria aurífera, por outro lado" (Mandel, 1982, p. 40-41). Esta análise permitirá aferir se a subida permanente dos preços no período pós- $2^{\mathrm{a}}$ Guerra Mundial é atribuível a um aumento mais rápido da produtividade do trabalho no ramo aurífero.

Apoiando-se numa miríade de dados estatísticos, Ernest Mandel defende que uma "estimativa realista" permite afirmar que "o valor de um grama de ouro caiu para metade entre 1907 e 1967" (Mandel, 1976, p. 423, itálico no original). Por seu turno, no que se refere à força produtiva do trabalho nos demais ramos da economia, Mandel utiliza os EUA como exemplo dos países capitalistas mais desenvolvidos. O autor conclui que, no mesmo período histórico, a produtividade do setor industrial aumentou 520\%, enquanto a produtividade do setor agrícola aumentou 540\% (Mandel, 1976, p. 424). De acordo com Mandel,

Isto significa que o valor médio das mercadorias produzidas nos países imperialistas [i.e., nos países capitalistas mais desenvolvidos] é atualmente [i.e., no início dos anos 70] cinco ou seis vezes menor do que no período anterior à $1^{\text {a }}$ Guerra Mundial. Visto que o valor do ouro diminuiu apenas $50 \%$ desde essa altura, os preços expressos em ouro das mercadorias deveriam ser, em média, três vezes menores do que em 1907. Na verdade, porém, os preços das

\footnotetext{
${ }^{5}$ Que, em termos marxianos, não pode ser considerada inflação strictu sensu, pois a subida dos preços é reconduzível a alterações das relações de valor.
} 
mercadorias, expressos em dólares de papel, são três vezes superiores àqueles de 1907. (Mandel, 1976, p. 425, itálico nosso)

Na prática, assistiu-se à “desvalorização nônupla do dinheiro", portanto, à subida geral do nível de preços que ocultou "a queda substancial do valor das mercadorias expresso em quantidades de ouro", isto é, do seu valor de troca (Mandel, 1976, p. 425 itálico no original). Segundo Geert Reuten, a grande questão que se coloca consiste, então, em saber porque é que, entre 1944 e o início da década de 1970, "se verificou uma inflação lenta mas persistente, ao invés de um decréscimo do nível geral de preços internacional, em consonância com os aumentos da produtividade" do trabalho industrial e agrícola (Reuten, 2003, p. 46). Reuten recorda que, durante o século XIX, esses aumentos da produtividade "traduziam-se, de fato, (...) em diminuições dos preços" (Reuten, 2003, p. 45).

Dado que o aumento da força produtiva do trabalho foi superior nos demais ramos de negócio face àquele verificado no ramo da mineração aurífera, a explicação da inflação permanente das últimas décadas terá forçosamente de ser procurada alhures._O nível geral de preços pode sofrer alterações por via da modificação do padrão de preços. Viu-se em 3.2 que o estabelecimento do padrão de preços "depende apenas da lei e do poder do Estado", sendo, "de certo modo, arbitrário" (Prado, s.d., p. 5).

É evidente que, ao longo do século XX, múltiplos países desvalorizaram em diversas ocasiões o seu padrão de preços. Essa desvalorização torna, em particular, o capital autóctone "mais competitivo no plano internacional" (Mattick, 2010, p. 238) e favorece as exportações (Mandel, 1971, p. 263). Todavia, por outro lado, a desvalorização da moeda "aumenta os preços das importações" (Mandel, 1971, p. 263) e, claro, provoca um aumento dos preços no mercado doméstico.

Acresce que "como qualquer país independente tem o poder de desvalorizar a sua moeda" (Mattick, 2010, p. 238), existe o risco de se desencadear "um efeito bola de neve" (Mandel, 1971, p. 263), em que todos os países procuram melhorar artificialmente a sua balança comercial através de uma guerra cambial. Em última instância, é "a estrutura real do capital, e não a estrutura monetária, que vai determinar a competitividade relativa dos diversos países" (Mattick, 2010, p. 238).

Mas mais importante do que a desvalorização cambial ser uma arma concorrencial com limitações óbvias é, para o assunto que nos interessa, o fato de a desvalorização do padrão de preços nacional promovida pelo Estado ser incapaz de explicar o aumento contínuo e simultâneo dos níveis de preços em todos os países ao longo da segunda metade do século XX. A inflação permanente assume-se como uma realidade incontornável mesmo nos países com moedas fortes, nomeadamente nos países capitalistas ocidentais mais desenvolvidos.

Com vista a explicar esta situação, será proveitoso recuperar novamente os dados da investigação de Ernest Mandel. $\mathrm{O}$ autor apresenta fortes evidências empíricas que parecem comprovar a teoria da emissão excessiva de meio circulante (cf. 6.2) e, em parte, a teoria do conflito distributivo (cf. 6.3). Mandel volta a utilizar os EUA como exemplo de uma nação capitalista avançada, analisando o período pós- $2^{a}$ Guerra Mundial. Mandel salienta 
que "é (...) necessário correlacionar (...) o aumento da quantidade de dinheiro [em circulação] comparativamente ao valor do produto total (i.e., o volume da produção multiplicado pelo valor médio das mercadorias), tomando em consideração a velocidade de circulação do dinheiro" (Mandel, 1976, p. 421). Os principais resultados do estudo do economista belga podem ser elencados do seguinte modo:

a) No período compreendido entre 1945 e 1967 a quantidade de dinheiro em circulação aumentou cerca de 90\%, sendo que em 1967 era sete vezes mais elevada do que em 1929 e nove vezes mais elevada do que em 1907 (Mandel, 1976, p. 427);

b) No que se refere ao output industrial, registou-se um aumento de $70 \%$ entre 1915 e 1929 (Mandel, 1976, p. 427) e de 400\% entre 1929 e 1967 (Mandel, 1976, p. 428); logo, o output industrial era aproximadamente 5 vezes superior em 1967 face a 1915

c) A velocidade de circulação do dinheiro registou uma pequena aceleração entre 1915 e 1929 (Mandel, 1976, p. 427), mas caiu 30\% nos anos que se seguiram à Grande Depressão (Mandel, 1976, p. 427). A velocidade de circulação duplica entre 1945 e 1967, alcançando outra vez o ritmo de 1929 (Mandel, 1976, p. 427428). É possível constatar que a diferença entre a velocidade de circulação do dinheiro em 1915 e aquela verificada em 1967 é residual, ou seja, elas são, para todos os efeitos, bastante semelhantes;

d) Ainda que o valor médio das mercadorias não tivesse sofrido qualquer alteração, seria preciso aproximadamente cinco vezes mais dinheiro, em 1967, para circular a massa de mercadorias produzida, e não nove vezes mais. Todavia, sabemos que o valor médio - o preço expresso em ouro - das mercadorias diminuiu três vezes entre 1907 e 1967 (Mandel, 1976, p. 425). ${ }^{6}$

$\mathrm{Na}$ ótica do autor, a conclusão é evidente:

Estamos perante uma inegável massa inflacionária de dinheiro que não corresponde a nenhum
aumento proporcional da produção de mercadorias. Consequentemente, o nível médio de preços
em 1967 era duas vezes mais elevado do que em 1929 e três vezes mais elevado do que em
1907. O aumento da quantidade de dinheiro, i.e., do papel-moeda e do dinheiro bancário, foi
portanto a causa técnica inequívoca e direta da inflação do dólar. A quantidade de dinheiro
[circulante] cresceu muito mais rapidamente do que o volume do output material - movendo-
se na direção contrária à queda acentuada dos valores (preços expressos em ouro) da totalidade
das mercadorias. (Mandel, 1976, p. 428)

Em suma, o recurso ao dinheiro simbólico como meio de circulação "pode velar a tendência deflacionária que é produzida pelo progresso da força produtiva do trabalho" na indústria (Prado, 2011, p. 9). A emissão excessiva de meio circulante provoca a desvalorização do papel-moeda - e do dinheiro simbólico em geral - e um consequente aumento dos preços de mercado medidos num certo padrão de preços (euro, dólar, iene, etc.). Estamos perante um aumento dos preços das mercadorias concomitante à diminuição

\footnotetext{
${ }^{6}$ Veja-se a citação anterior de Mandel destacada do corpo do texto.
} 
do seu valor expresso em ouro (i.e., em termos do tempo de trabalho socialmente necessário). $O$ aumento fictício dos preços esconde a diminuição real do valor.

\section{Conclusão}

Conforme foi exposto, todas as teorias marxistas da inflação atribuem este fenômeno ao desfasamento do nível geral dos preços face ao valor determinado pelo trabalho socialmente necessário despendido na economia no seu conjunto: "o nível dos preços «descola» relativamente ao nível dos valores" (Lipietz, 1985, p. 75). As razões apontadas para esse desfasamento são contudo diferentes.

A teoria do capital monopolista associa a inflação "ao poder (...) das grandes empresas" (Saad Filho, 2000, p. 342), que são capazes de impor preços de mercado substancialmente superiores aos preços de produção, i.e., preços de monopólio. A teoria da elasticidade de criação monetária explica a inflação através da multiplicação de símbolos monetários desprovidos de valor que funcionam como meio de circulação. A teoria do conflito distributivo atribui a inflação à luta pela partilha do valor criado: em particular, o aumento dos preços permite comprimir os salários reais e travar artificialmente a descida dos lucros.

As evidências empíricas apresentadas permitem tirar duas grandes conclusões. Em primeiro lugar, a forte diminuição da produção de valor, provocada pelo aumento colossal da força produtiva do trabalho - sobretudo em resultado da $3^{\text {a }}$ Revolução Industrial -, é ocultada através da inflação permanente, como prevê a teoria do conflito distributivo. Em segundo lugar, essa inflação permanente é "um traço específico dos sistemas monetários contemporâneos dominados pelo dinheiro de crédito criado pelos bancos e pelo dinheiro fiduciário criado pelo Estado" (Saad Filho, 2000, p. 345), como preconiza a teoria da emissão excessiva de meio circulante.

Assiste-se a um movimento quasi-autônomo dos preços, na medida em que eles "perdem contacto com as relações reais de produção e de circulação" (Mattick, 1983, p. 79). Em especial, o fim do regime de Bretton Woods, e da correspondente conversibilidade do dólar em ouro, abriu caminho à multiplicação exponencial dos signos monetários. A emissão de meio circulante deixou de obedecer a qualquer limite formal, enquanto um volume estratosférico de crédito alimentou a reprodução simulada do capital sob a forma de capital fictício:

A contradição do capital financeiro é, assim, aquela de uma multiplicação de signos [monetários] que pretendem ser capital ou representar capital, mas que não possuem qualquer relação com o crescimento do capital materializado num processo de produção de mais-valia. Os signos multiplicam-se independentemente do valor realmente criado. Até ao momento em que o crash vem demonstrar que eles não passam de capital fictício. (Thomas, 2009, p. 46-47)

A relação cada vez mais distante e complexa do dinheiro simbólico com o ouro significa que a função de medida dos valores, imprescindível para "a mediação do processo integrado de produção, circulação e distribuição de mais-valia - que é feita por meio do dinheiro - se torna" perigosamente "instável” (Barbosa, 2010, p. 149). Para além disso, a 
exacerbação da "natureza especulativa dos lucros" (Barbosa, 2010, p. 149) faz o modo de produção capitalista caminhar no fio da navalha. O declínio da taxa (e da massa) de lucro manifestar-se-á, de forma violenta, mais cedo ou mais tarde, não podendo ser protelado indefinidamente por meio de subterfúgios monetários, creditícios ou bolsistas. A realidade recalcada impor-se-á inexoravelmente à ficção mirabolante.

\section{Agradecimentos}

Quero agradecer o apoio financeiro concedido pela Universidade de Lisboa, no âmbito de uma Bolsa de Doutoramento, e da Fundação para a Ciência e a Tecnologia (Projeto UID/SOC/04521/2019).

\section{Referências}

BARBOSA, G. Marx e a Inflação: Uma interpretação do fenômeno com base na teoria do valor-trabalho. Tese (Mestrado). Universidade Federal do Paraná, Curitiba, 2010.

BREWER, A. A guide to Marx's Capital. Cambridge University Press, 1984.

DE BRUNHOFF, S. Marx on Money. Urizen Books, 1976.

GORENDER, J. Introdução. In: MARX, K. Para a Crítica da Economia Política; Salário, Preço e Lucro; O Rendimento e as suas Fontes: A Economia Vulgar. Abril Cultural, 1982.

GUERRERO, D. Un resumen completo de El Capital de Marx. Maia Ediciones, 2010. http://www.rebelion.org/docs/20118.pdf.

HARVEY, D. The Limits to Capital. Verso, 2006.

HARVEY, D. A Companion to Marx's Capital. Verso, 2010.

HEINRICH, M. An Introduction to the Three Volumes of Karl Marx's Capital. Monthly Review Press, 2012.

ITOH, M. e LAPAVITSAS, C. Political Economy of Money and Finance. Palgrave Macmillan, 1999.

JACOBI, O., BERGMANN, J. e MUELLER-JENTSCH, W. Problems in Marxist Theories of Inflation. Kapitalistate, n. 3, p. 107-125, 1975

JAPPE, A. As Aventuras da Mercadoria: Para uma nova crítica do valor. Antígona, 2006.

LIPIETZ, A. Crise et inflation: pourquoi?. François Maspero, 1979.

LIPIETZ, A. The Enchanted World: Inflation, Credit and the World Crisis. Verso, 1985. 
MANDEL, E. Marxist Economic Theory, Volume I. Monthly Review Press, 1971. MANDEL, E. Late Capitalism. New Left Books, 1976.

MANDEL, E. Introduction. In: MARX, K. Capital: A Critique of Political Economy, Volume I. Penguin Books, 1982.

MARX, K. Para a Crítica da Economia Política. In: MARX, K. Para a Crítica da Economia Política; Salário, Preço e Lucro; O Rendimento e as suas Fontes: A Economia Vulgar. Abril Cultural, 1982.

MARX, K. O Capital: Crítica da Economia Política. Livro Terceiro: O Processo Global da Produção Capitalista, Tomo 2. Editora Nova Cultural, 1986.

MARX, K. O Capital: Crítica da Economia Política. Livro Primeiro: O Processo de Produção do Capital, Tomo 1. Editora Nova Cultural, 1996a.

MARX, K. Salário, Preço e Lucro. In: MARX, K. O Capital: Crítica da Economia Política. Livro Primeiro: O Processo de Produção do Capital, Tomo 1. Editora Nova Cultural, 1996b.

MARX, K. Grundrisse: Manuscritos Econômicos de 1857-1858. Esboços da Crítica da Economia Política. Boitempo Editorial, 2011.

MATTICK, P. Economics, Politics, and the Age of Inflation. M.E. Sharpe Inc, 1978. https://libcom.org/files/Paul\%20Mattick\%20Economics\%20Politics\%20and\%20The\%20 Age\%20of\%20Inflation.pdf.

MATTICK, P. Marxism: Last Refuge of the Bourgeoisie?. M.E. Sharpe Inc., 1983.

MATTICK, P. Marx \& Keynes: Os Limites da Economia Mista. Antígona, 2010.

NELSON, A. Marx's Concept of Money: The God of Commodities. Routledge, 1999.

PRADO, E. Dinheiro: Medida dos Valores e Padrão dos Preços, s.d.. https://nunomiguelmachado.files.wordpress.com/2012/01/artc2ba-dinheiro-medidavalores-e-prado.pdf.

PRADO, E. Da crise e da inflação - uma abordagem marxista, 2011.

https://eleuterioprado.files.wordpress.com/2011/09/baixar-aula-8-cc3b3pia.pdf.

PRADO, E. Da controvérsia brasileira sobre o dinheiro mundial inconversível. Revista da Sociedade Brasileira de Economia Política, n. 35, p. 129-152, 2013.

PRADO, E. Do dinheiro-ouro ao dinheiro fictício, 2016.

https://eleuterioprado.wordpress.com/2016/09/17/dinheiro-ficticio-ii/do-dinheiro-ouroao-dinheiro-ficticio/. 
REUTEN, G. On «Becoming Necessary» in an Organic Systematic Dialectic: The Case of Creeping Inflation. In: ALBRITTON, R.; SIMOULIDIS, J. (Ed.). New Dialectics and Political Economy. Palgrave Macmillan, 2003.

SAAD FILHO, A. Inflation theory: A critical literature review and a new research agenda. Research in Political Economy, vol. 18, p. 335-362, 2000.

DOI: https://doi.org/10.1016/S0161-7230(00)18014-9

SHAIKH, A. Capitalism: Competition, Conflict, Crises. Oxford University Press, 2016.

SHORTALL, F. The Incomplete Marx. Avebury, 1994.

THOMAS, T. L'hégémonie du capital financier et sa critique. Editions Albatroz, 1999.

THOMAS, T. La Crise: Laquelle? Et après?. Contradictions, 2009. 